\title{
Correlations Between Severity of Disease with Anxiety Levels in Glaucoma Patients
}

\author{
Maulida Zahra ${ }^{1}$, Arief Wildan ${ }^{2}$, Riski Prihatningtias ${ }^{2}$, Fifin Luthfia Rahmi ${ }^{2 *}$ \\ ${ }^{1}$ Medical Faculty, Diponegoro University, Indonesia \\ ${ }^{2}$ Teaching Staff, Ophthalmology Department, Diponegoro University, Indonesia
}

Keywords:

Anxiety level

The severity of glaucoma TMAS scale

*) Correspondence to:

flrahmi@yahoo.com

Article history:

Received 29-05-2020

Accepted $25-06-2020$

Availableonline 01-07-2020

\begin{abstract}
Background: Glaucoma is a group of diseases consisting of optic neuropathy characterized by damage to the retinal nerve fibres and narrowing of the visual field accompanied by increased intraocular pressure as a risk factor. Vision loss in glaucoma patients is considered as a separate stressor. Besides that, decrease visual function can also cause a person to lose his job and loss of social functions. This can trigger anxiety to depression.

Objective: To analyze the correlations between the severity of disease with anxiety levels in glaucoma patients.

Methods: This was an observational analytic study with a cross-sectional design. Subjects were taken by consecutive sampling with inclusion criteria were patients with moderate or severe glaucoma, able to follow the interview process and 30-80 years old. The exclusion criteria of this study were patients who were taking antianxiety, antidepressant, or antipsychotic drugs and having other serious/chronic disease such as heart disease, diabetes, or hypertension. Anxiety level was assessed based on the Taylor Manifest Anxiety Scale (TMAS) questionnaire. Analysis of the data using the Spearman Correlation test.

Results: Sixty-five glaucoma patients who underwent treatment in out-patient department dr. Kariadi hospital was involved in this study. A significant correlation was obtained between the severity of glaucoma and the level of anxiety $(p=0.004)$. Strong statistical correlation between variables included in the weak category $(0.357)$. The highest anxiety level in glaucoma patients was moderate anxiety level $(64.6 \%)$, followed by mild anxiety level $(23.1 \%)$ and severe anxiety level $(12.3 \%)$. Conclusion: There was significant correlation between the severity of the disease and the level of anxiety in glaucoma patients.
\end{abstract}

DIMJ, 2020, 1(1), 16-20 DOI: https:/ / doi.org/ 10.14710/dimj.v1i1.7926

\section{Introduction}

The glaucoma is a group of diseases consisting of optic neuropathy characterized by retinal nerve fibre layer damage and visual field constriction is accompanied by an increase in intraocular pressure as a risk factor for glaucoma. ${ }^{1}$ Become the second leading cause of blindness in the world. ${ }^{2}$

World Health Organization (WHO) states that there are 285 million people worldwide suffer from visually impaired, 39 million of them are blind. In 2020 it is predicted that glaucoma patients worldwide will increase by 76 million, with the highest proportion found in Asia and Afrika. ${ }^{3}$ According to the Ministry of Health of the Republic of Indonesia, the prevalence of glaucoma in Indonesia is $4.6 \%$, the highest in Jakarta $(1.85 \%)$, followed by Aceh Province (1.28\%), Riau Islands (1.26\%), Central Sulawesi (1.21\%), West Sumatra $(1.14 \%)$ and the lowest were Riau Province $(0.04$ $\%)^{4}$

Vision loss in glaucoma patients is considered as a separate stressor. Loss of both the unilateral and bilateral field of view can lead to a decrease in productivity and independence. Moreover, blindness can cause people to lose jobs and the loss of social function. This can trigger anxiety to depression. ${ }^{5}$

Anxiety is a response to a danger that the source is unknown, internal, vague, or conflictual. The sensation that is often experienced by almost all humans. Sweating, sweating, palpitations, stiffness in the chest, and mild stomach difficulties. ${ }^{6}$ 


\section{Method}

This an observational analytic design with the cross-sectional approach. The independent variable of this study is the severity of glaucoma and the dependent variable was the level of anxiety. Subjects were obtained by consecutive sampling with a total of 65 Glaucoma patients undergoing therapy at the Outpatient Eye department of RSUP dr. Kariadi Semarang, who fulfils the inclusion and exclusion criteria. Anxiety level was assessed by filling in the Taylor Manifest Anxiety Scale (TMAS) questionnaire.

The inclusion criteria of this study were patients with moderate or severe glaucoma, able to follow the interview process and 30-80 years old. The exclusion criteria for this study were patients who were taking anti-anxiety, antidepressant, or antipsychotic drugs and having other serious/chronic illnesses such as heart disease, diabetes, or hypertension.

The data obtained were processed using a computer program. Data normality was tested using the Kolmogorov-Smirnov test and the correlation test was performed to see the relationship between the severity and anxiety levels using the Spearman Correlation test.

\section{Result}

In this study, respondents were described based on age, sex, type of glaucoma, eyes suffering from glaucoma, degree of CDR and level of anxiety.
Table 1.General characteristic subject

\begin{tabular}{lcc}
\hline Variable & Frequency & $\begin{array}{c}\text { Percentage } \\
(\%)\end{array}$ \\
\hline Age & & \\
$>60$ years old & 26 & 40 \\
$\quad$ <60 years old & 39 & 60 \\
Gender & & \\
$\quad$ Male & 35 & 53.8 \\
$\quad$ Female & 30 & 46.2 \\
Glaucoma Type & & \\
Open Glaucoma & 27 & 41.5 \\
Closure Glaucoma & 34 & 52.3 \\
$\quad$ Secondary Glaucoma & 4 & 6.2 \\
Glaucoma Eyes & & \\
Right & 24 & 36.9 \\
Left & 18 & 27.7 \\
Right-Left & 23 & 35.4 \\
Severity of Glaucoma & & \\
$\quad$ Moderate & 30 & 46.2 \\
$\quad$ Severe & 35 & 53.8 \\
Anxiety Level & & \\
Mild & 15 & 23.1 \\
Moderate & 42 & 64.6 \\
Severe & 8 & 12.3 \\
\hline
\end{tabular}

Sixty-five subjects were involved in this study, a male was much more $(53.8 \%)$ than female and $60 \%$ of them were under 60 years old. Most frequent types of glaucoma that the subjects suffered from was closed-angle glaucoma (52.3\%). The laterality of the eye with glaucoma is a right eye (36.9\%). Thirty-five subjects $(53.8 \%)$ had severe glaucoma and the highest level of anxiety of the subjects was moderate $(64.6 \%)$.

The level of anxiety assessment that was used has two question characteristics, favourable and unfavourable. Favourable questions are directed towards feelings of anxiety. Conversely, unfavourable questions do not lead to feelings of anxiety. So that the favourable nature of the questions found as many as 56 respondents $(86.2 \%)$ answered "yes" to the statement of the difficulty of concentration on a problem and was afraid of the difficulties faced. 
Table 2. Anxiety Levels in Glaucoma Patients Based on Severity

\begin{tabular}{llllll}
\hline & \multicolumn{4}{c}{ Anxiety Level } & \multirow{2}{*}{ Total } \\
\cline { 2 - 5 } & & Mild & Moderate & Severe & \\
\hline $\begin{array}{l}\text { Degree of } \\
\text { Severity }\end{array}$ & Moderate & $1(36.7 \%)$ & $18(60 \%)$ & $11(3.3 \%)$ & $100 \%$ \\
& Severe & $4(11.4 \%)$ & $24(68.6 \%)$ & $7(20 \%)$ & $100 \%$ \\
\hline
\end{tabular}

Respondents who have a moderate degree of severity of the highest anxiety levels that anxiety levels were about 18 people (60\%). In contrast, respondents who have a moderate degree of severity of the highest anxiety levels are levels of anxiety were also as many as 24 people $(68.6 \%)$.

Table 3. Correlations between the severity of glaucoma with anxiety levels

\begin{tabular}{lll}
\hline & & Anxiety Level \\
\hline $\begin{array}{l}\text { Degree of } \\
\text { Severity }\end{array}$ & Significant (P) & 0.004 \\
& $\begin{array}{l}\text { The correlation } \\
\text { coefficient }(\mathbf{r})\end{array}$ & 0.357 \\
\hline
\end{tabular}

*Significant ( $\mathrm{p}<0.05)$; Correlation (strong: $r>0.5$; weak: $r$ $<0.5)$

The data normality test results obtained abnormal data distribution $(p<0.05)$ where the distribution of the two data variables is not normal so that the correlation test is done using the Spearman Correlation test to find out whether there is a strong or weak relationship between the severity of glaucoma with anxiety levels.

Data normality test obtained p-value $<0.05$ which means that there is a significant relationship between the severity of glaucoma with anxiety levels. While the correlation (r) between the severity of glaucoma with the anxiety level shows the results of $r<0.5$ which means there is a weak relationship between the two variables.

\section{Discussion}

The results of an assessment of anxiety levels in general from mild to severe degrees found that the most anxiety levels were moderate degrees $(64.6 \%)$, followed by mild degrees (23.1\%) and severe degrees (12.3\%). This is similar to the research conducted by Bura, et al7 that found the majority of respondents suffer from moderate anxiety $(61.2 \%)$, followed by mild degrees (24.1\%) and severe degrees (14.7\%).

The anxiety level of glaucoma patients in this study was measured using a questionnaire but also depends on the subjective evaluation of the sufferer. Many factors are related to the anxiety level of glaucoma sufferers, including visual disability, problems taking glaucoma medication, side effects of medication, treatment mismatch, or mental health of sufferers.

In this study, most are worried about the problem and difficult to concentrate on a problem. Everyone has felt anxious and worry. This is a natural thing to be felt. However, the worry that does not stop will affect the psychological state and develops anxiety. Many things were worried by respondents in daily life such as quality of life, economy and family problems related to the disease. The anxiety experienced causes a person to become anxious and anxiety is an expression of anxiety. ${ }^{8}$ Although many experience anxiety about certain things, respondents can still control that worry by praying.

In this study, half of the respondents experienced headaches. Anxiety will cause someone to feel like floating. The state of feeling flit is caused due to nutritional deficiencies in the body. In the anxious state, there will be a change in the balance of acidic bases in the blood resulting in hypocapnia which causes a person to feel dizzy like floating. ${ }^{9}$

Rest and sleep are basic human needs. Adequate sleep is needed by the body to function normally and carry out the recovery process of stamina to be in an optimal condition. ${ }^{10}$ Anxiousness experienced by respondents will cause a person to have difficulty starting to sleep and often waking up in the middle of the night or having trouble sleeping. This happens because of fears of illness and imagines big problems that will occur. ${ }^{11}$ The results of this study found that half of the respondents had difficulty starting sleep and insomnia.

Anxiety is a deep and pervasive concern related to feelings of uncertainty and helplessness. Behaviour theory states that anxiety is the result of frustration due to various things that affect the individual in achieving the desired goals. In this case for the examples a patient who wants to recover from his illness, and therefore it will trigger anxiety. ${ }^{12}$

This study categorizes the severity variable into two categories, moderate and severe based on a cupdisc ratio. From the analysis, it was found that most respondents had a severe severity. Subjects who have severe severity tend to have moderate anxiety and subjects who have moderate severity also tend to have moderate anxiety. 
Based on the results of interviews with subjects, it was found that there was an influence of the duration of treatment and the surrounding environmental conditions. The length of treatment that has been undertaken for more than a year resulted in respondent acceptability to the disease that they were suffered from. This is similar to research done by Gupta, et al $^{13}$, where respondents with glaucoma are less than five years have utility value lower than respondents with glaucoma for more than ten years. This shows that the longer they suffer from glaucoma, the more respondents will understand and adapt to the disease.

The surrounding environmental conditions such as family support and assistance also affect the level of anxiety. This is similar to the research conducted by Ika, et al ${ }^{14}$ who stated that there was a significant relationship between family support and anxiety levels with powerful strength. Although respondents who have severe stage can experience mild and moderate anxiety due to the influence of the duration of treatment and the surrounding environment. Conversely, respondents who have moderate severity can experience severe anxiety as well. So in this study, it can be concluded that there is a weak correlation between the severity of glaucoma and the level of anxiety.

Quality of life is a measure that is difficult to assess by doctors, but it is essential for sufferers. Decreased quality of life in people with glaucoma can occur due to various reasons, including anxiety about blindness from the start when diagnosed with glaucoma, decreased visual function that disrupts daily activities, treatment discomfort, side effects, and the cost of treatment itself. ${ }^{15}$ Factors affecting the quality of life of glaucoma patients include education, knowledge, age, sex, occupation, duration of illness, treatment history, severity, eye acuity, wide field of view, history of illness, family history and intraocular pressure. ${ }^{16}$

\section{Conclusion}

There are a significant relationship and a weak correlation between the severity of the disease and the level of anxiety in glaucoma patients. The level of anxiety in patients with glaucoma is the most moderate levels of anxiety, followed by the level of mild anxiety and severe anxiety level. The most anxiety level at moderate severity is moderate anxiety level while the most anxiety level at severe severity level is moderate anxiety level.

\section{Ethical Approval}

Ethical clearance was obtained from Research Ethics Commission Medical Faculty Diponegoro University with the number of 216/EC/KEPK/FKRSDK/2019.

\section{Conflicts of Interest}

The authors declare no conflict of interest.

\section{Funding}

No specific funding was provided for this article.

\section{Author Contributions}

Writing-original draft preparation, Maulida Zahra; writing-review and editing, Dr. dr. Fifin Luthfia Rahmi. M. S, Sp. M(K)

\section{Acknowledgments}

This work was supported by Department of Ophthalmology, Faculty of Medicine, Diponegoro University.

\section{References}

1. Zeyen T. Visual field examination in daily practice. Acta Ophthalmol. 2012;90:0-0. doi:10.1111/j.1755-3768.2012.1653.x

2. Fleischman D, Davis RM, Zhang X, Lin F-C, Olson DJ, Le P. The Association Between Glaucoma, Anxiety, and Depression in a Large Population. Am J Ophthalmol. 2017;183:37-41. doi:10.1016/j.ajo.2017.07.021

3. Kemenkes RI. World Glaucoma Week 2017, Beat Invisible Glaucoma, Cegah Kebutaan Akibat Glaukoma. Ditjen Yankes.

4. RI D. Riset Kesehatan Dasar (RISKESDAS) 2007. Lap Nas 2007. 2007. doi:1 Desember 2013

5. Mohamed EA, Bayoumi OR, Draz SF. Impact of an educational programme on knowledge, beliefs, practices and expectations about care among adolescent glaucoma patients in Cairo. East Mediterr Health J. 2011.

6. Kaplan HI, Sadock B, Grebb JaA. Sinopsis Psikiatri. In: 1. ; 2010.

7. Bura Aedua. Gambaran Tingkat Kecemasan Pada Lansia Dengan Hipertensi Di Puskesmas Nita Kabupaten Sikka NTT.

8. Stuart GW, Sundeen SJ. Buku saku keperawatan jiwa. Jakarta EGC. 2007.

9. Smeltzer SC, Bare B. Buku Ajar Keperawatan Medikal Bedah Brunner \& Suddarth (Vol. III). M Ester, Penyunt, A Hartono, HY Kuncara, ES Siahaan, A Waluyo, Penerj) 
Jakarta EGC. 2006.

10. Guyton AC, Hall JE. Buku ajar fisiologi kedokteran edisi 11. Jakarta EGC. 2007:81-85.

11. Pramana KD, Okatiranti O, Ningrum TP. Hubungan Tingkat Kecemasan Dengan Kejadian Hipertensi Di Panti Sosial Tresna Werdha Senjarawi Bandung. J Keperawatan BSI. 2016;4(2).

12. Hampshire S. 3. Thought and Action. 2016.

13. Gupta V, Srinivasan G, Mei SS, Gazzard G, Sihota R, Kapoor KS. Utility values among glaucoma patients: an impact on the quality of life. Br J Ophthalmol. 2005;89(10):1241-44.

14. Al Aziz IH, Sudiro S. Hubungan dukungan keluarga dengan tingkat kecemasan pada pasien gagal ginjal kronis yang menjalani hemodialisis di RSUD Dr. Soehadi Prijonegoro Sragen. J KEPERAWATAN Glob. 2017;2(1).

15. Iester M, Zingirian M. Quality of life in patients with early, moderate and advanced glaucoma. Eye. 2002;16(1):44.

16. Van Kamp I, Leidelmeijer K, Marsman G, De Hollander A. Urban environmental quality and human well-being: Towards a conceptual framework and demarcation of concepts; a literature study. Landsc Urban Plan. 2003;65(1-2):5-18. 